Rev. Biol. Trop., 47(4): 1111-1115, 1999

www.ucr.ac.cr www.ots.ac.cr www.ots.duke.edu

\title{
Reproductive characteristics of the black-tailed brush lizard, Urosaurus nigricaudus (Phrynosomatidae)
}

\author{
Heidi L. Romero-Schmidt, Alfredo Ortega-Rubio and Marcos Acevedo-Beltran \\ Centro de Investigaciones Biologicas del Noroeste, Apdo Postal 128, La Paz 23000, BCS, México.Fax: (112)327 60. \\ E-mail: heidi@cibnor.mx
}

Received 24- IX-1998. Corrected. 7-IV-1999. Accepted 16-IV-1999

\begin{abstract}
The reproductive characteristics of Urosaurus nigricaudus at El Comitán, Baja California Sur, México, were determined through the necropsy of 33 males and 60 females during 1992. The average size of clutch per female was $4.06 \pm 1.86$ eggs; 3.58 eggs for the first clutch and 4.75 eggs for the second clutch. Testicular size exhibits two peaks, one each in May and August. Female and male reproductive cycles are synchronized. In comparison with other Urosaurus species, $U$. Nigricaudus is atypical because males have two peaks of testicular mass.
\end{abstract}

Key words. Baja California Sur, México, black-tailed brush lizard, Urosaurus nigricaudus, reproduction.

The Cape black-tailed brush lizard is a small lizard (44-to 50-mm snout-vent length, Stebbins 1985), endemic to the Cape Region, B.C.S., México. Its distribution includes the southern part of the Baja California Peninsula. The main distinguishing characteristic of this lizard is a sooty to blackish tail, and a row of gray or dusky to black blotches or crossbars on each side of the back (Stebbins 1985). Although $U$. nigricaudus is an abundant and conspicuous diurnal lizard in the Cape region (Galina 1994), there is no previous study on the reproductive biology of this species.

Field work was done at "El Comitan," in the northern part of the Cape Region, $20 \mathrm{~km}$ north of $\mathrm{La} \mathrm{Paz}\left(24^{\circ} 10^{\prime} \mathrm{N} ; 110^{\circ} 30^{\prime} \mathrm{W}\right)$. " $\mathrm{El}$ Comitan,"is a coastal lowland $(10 \mathrm{~m}$ above sea level), with mud-sandy soils (Romero-Schmidt et al. 1994). The area is located in the phytogeographical province of the Cape Region, of arid-tropical features. The site presents a bimodal rain pattern, on late summer and winter seasons (León de la Luz et al. 1996). The climate of the zone is arid-warm with an average annual temperature of $23.9^{\circ} \mathrm{C}$, and mean annual precipitation of $62 \mathrm{~mm}$, concentrated during the summer months (Alvarez, et al. 1989). The predominant flora of this region is xerophytic scrub (León de la Luz and Troyo 1985).

\section{MATERIALS AND METHODS}

During the first three days of each month from April 1992 through March 1993, we traversed the zone in search of $U$. nigricaudus adults. Each lizard observed was collected using a rubber band. In the laboratory, the following data were recorded: Snout-vent length (SVL), tail length and body mass. For females, ovaries and oviducts were examined. We counted, measured and weighed all unyolked and yolked follicles, and corpora lutea in the ovaries, and oviducal eggs. Testes size and mass were recorded for each male. Fat 
bodies of both sexes were weighed. All the linear measurements were made to the nearest $0.1 \mathrm{~mm}$ with a metallic caliper and the masses to the nearest $0.0001 \mathrm{~g}$ with a digital balance.

\section{RESULTS}

During the winter months, there were no signs of activity for adult males and females. So, the analysis performed does not include such months.

Females: The first females were collected in April, and some of them exhibited yolked follicles $(50 \%)$ and oviducal eggs $(60 \%)$ (Table 1). During June, $50 \%$ of the females showed signs of vitellum deposition and $50 \%$ exhibited oviducal eggs (Table 1). In July, only yolked follicles were present in $70 \%$ of the females. All the females collected during August exhibit oviductal eggs and corpora lutea (Table 1). In September, few females show eggs in the oviduct (20\%). For this reproductive phenology, we assume that there exist two reproductive peaks, during June and August, with two periods of clutch laying, July and September. Analysis with SVL as covariate revealed that ovarian masses are associated with SVL, and that there is a significant difference among the monthly analyzed ovarian masses $\left(r^{2}=0.229 ; F_{(5,53)}=88.35\right.$; $P<0.001$ ). Adjusted means of monthly ovarian masses are shown in Figure 1. Ovary mass decreases from April to June, and increases from July to August, the month when the mass reaches its maximum, and declines during September. The SNK test revealed there are significant differences among all pairs of months, except between May and September. Analysis of Covariance with SVL as a covariable was used to adjust the monthly means of female fat-body masses, because there is a significant effect of

TABLE 1

Results of the reproductive tract analysis of Urosaurus nigricaudus females collected during 1992

\begin{tabular}{|c|c|c|c|c|c|c|}
\hline & April & May & Jun & July & August & Sept \\
\hline $\mathrm{N}$ & 10 & 10 & 10 & 10 & 10 & 10 \\
\hline Snout-Vent Length (mm) & 39.2 & 38.2 & 37.0 & 37.9 & 38.65 & 41.16 \\
\hline$S$ & 1.4 & 0.79 & 0.64 & 0.75 & 0.76 & 1.37 \\
\hline Mass (g) & 2.04 & 1.99 & 1.80 & 1.89 & 1.98 & 2.07 \\
\hline$S$ & 0.111 & 0.087 & 0.08 & 0.06 & 0.08 & 0.13 \\
\hline Ovary mass (g) & 0.0175 & 0.0124 & 0.0106 & 0.0142 & 0.0181 & 0.0126 \\
\hline$S$ & 0.0014 & 0.0008 & 0.0002 & 0.0008 & 0.0009 & 0.0007 \\
\hline Fat-body mass (g) & 0.0064 & 0.0087 & 0.0119 & 0.0059 & 0.0004 & 0.0200 \\
\hline$S$ & 0.0005 & 0.0005 & 0.0004 & 0.0005 & 0.0001 & 0.0008 \\
\hline Follicles with vitellum $\mathrm{f}$ & 1.1 & 1.0 & 1.1 & 1.3 & 1.6 & 1.3 \\
\hline Oviductal eggs $\mathrm{f}$ & 5.4 & 5.8 & 7.4 & - & 3.46 & 7.1 \\
\hline Corpora lutea $\mathrm{f}$ & - & - & 2 & 2.8 & 1.9 & 0.7 \\
\hline$\%$ with vitellogenesis & 50 & 40 & 50 & 70 & 70 & 20 \\
\hline$\%$ with oviductal eggs & 60 & 60 & 50 & - & 100 & 20 \\
\hline$\%$ with corpora lutea & 40 & 30 & 50 & - & 100 & - \\
\hline
\end{tabular}




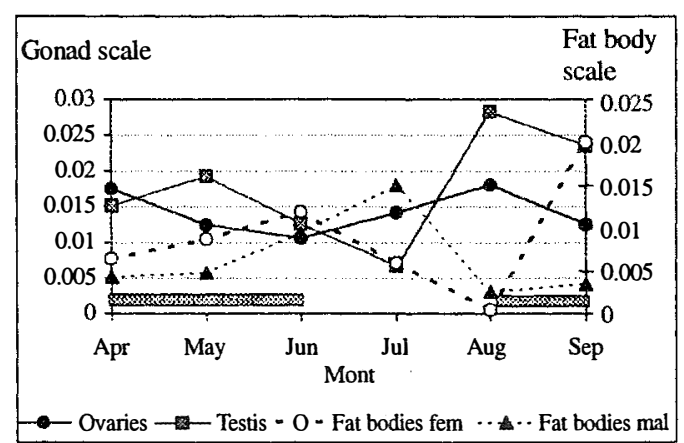

Fig.1. Urosaurus nigricaudus gonads and fat-body masses of the males and females. Means adjusted to snout vent length. The shaded bar at the bottom of graph means the presence of eggs in the females.

body mass on fat-body mass $\left(r^{2}=-0.092 ; P<0.05 ; F\right.$ $(5,53)=1387.2 ; \mathrm{P}<0.001)$. Female fat-body mass tended to increase from April to June, decline from July to August, and abruptly increased in September (Fig.1). An inverse relationship between ovarian and fat-body mass cycles may be observed from April to August (Fig.1). The correlation is significant $(Y=0.110-1.40 \mathrm{X} ; r=-$ $0.65 ; P<0.05)$.

Female reproductive phenology is shown in Figure 2. The female reproductive characteristics covered 6 months with two

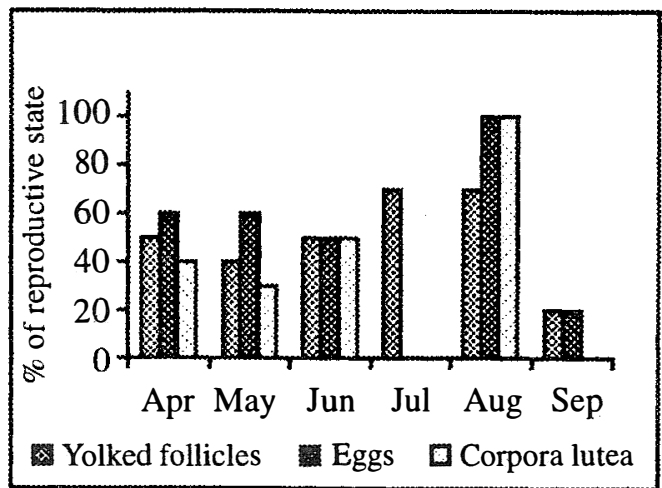

Fig.2. Urosaurus nigricaudus female reproductive phenology.

peaks, April and August. The average size of both clutches was $4.06 \pm 1.86$ eggs $(\mathrm{N}=29$; range 2- 6). The clutch size (CS) is a function of the female size $(Y=8.58-0.116 \mathrm{x})$, and there are a negative significant correlation coefficient; $(r$ (27) $=-0.42 ; P<0.05$ ) between female size and clutch size. However, the first clutch was smaller (3.58 eggs, range 2-4; $\mathrm{Y}=6.69-0.08 \mathrm{x} ; r_{(15)}$ $=-0.43 ; P<0.05)$, than the second one $(4.75$ eggs, range 4-6; $\left.\mathrm{Y}=10.99-0.16 \mathrm{x} ; r_{(10)}=-0.67 ; P<0.05\right)$.

Males: Reproductive data values from $U$. nigricaudus males are shown in Table 2. Analysis

TABLE 2

\begin{tabular}{|c|c|c|c|c|c|c|c|}
\hline \multicolumn{8}{|c|}{ Urosaurus nigricaudus male reproductive characteristics } \\
\hline & Apr & May & Jun & Jul & Aug & Sep & Oct \\
\hline $\mathrm{N}$ & 6 & 5 & 7 & 7 & 8 & 5 & 4 \\
\hline Snout-Vent Length(mm) & 61.48 & 64.66 & 65.4 & 62.76 & 63.10 & 61.25 & 57.15 \\
\hline$S$ & 0.98 & 1.17 & 1.43 & 0.92 & 2.86 & 1.29 & 1.41 \\
\hline Mass (g) & 5.52 & 6.33 & 7.05 & 6.29 & 6.35 & 6.17 & 5.46 \\
\hline$S$ & 0.07 & 0.57 & 0.23 & 0.08 & 0.42 & 0.06 & 0.181 \\
\hline Testís mass (g) & 0.019 & 0.028 & 0.048 & 0.028 & 0.026 & 0.023 & 0.008 \\
\hline$S$ & 0 & 0 & 0.003 & 0 & 0 & 0 & 0 \\
\hline Fat-body mass (g) & 0.008 & 0 & 0.0136 & 0.015 & 0.015 & 0.01 & 0 \\
\hline$S$ & 0 & 0 & 0 & 00 & 0 & 0 & \\
\hline Testis length (mm) & 3.62 & 4.18 & 4.42 & 4.01 & 3.74 & 3.53 & 2.97 \\
\hline$S$ & 0.28 & 0.196 & 0.064 & 0.055 & 0.177 & 0.071 & 0.032 \\
\hline
\end{tabular}

( $S=$ standard deviation) 
of Covariance, with SVL as a covariate, was used to adjust means of monthly testicular mass, because there is a significant effect of body mass on testicular mass $\left(r^{2}=0.145 ; F_{(5,28)}=74.2\right.$; $P<0.001)$. Adjusted monthly means of the testicular masses are shown in Figure 1, where it can be seen that testicular mass slowly increases from April to May, declines from June to July, and then abruptly increases to August. This increase is followed by a slow decline from August to September. The SNK test revealed that there are significant differences among all pairs of months. Male fat-body mass values are associated with $\operatorname{SVL}\left(r^{2}=0.04 ; F_{(5,28)}=127.2 ; P<0.001\right)$, and, thus, adjusted means were calculated on a monthly basis to examine seasonality in energy reserves (Fig.1). Males exhibit an increase from May to July in fat-body mass, which begins to decline to August. Energetic reserves in abdominal fat bodies remains relatively low during most months with a peak in July. SNK post-hoc tests revealed that there are differences among June, July, and August, and with other months. April, May, and September are equal statistically. Testicular development is inversely correlated with fat-body mass $(y=0.0132$ $-0.384 \mathrm{x} ; r=-0.81 ; P<0.05$ )(Fig. 1).

\section{DISCUSSION}

At "El Comitán," U. nigricaudus individuals are active from April through September. The male and female reproductive cycles are synchronized; both sexes reach two reproductive activity peaks: one during the spring (May-June) and a second during late summer (August). Fatbody depletion in male and female of $U$. nigricaudus are clearly associated with increased reproductive organs masses.

Comparing our results with a previous work on the same endemic species, we found that our results are coincident, in part, with the only study published (Asplund 1967). Asplund reported that individuals of this species collected during August were in reproductive activity. However, his study includes only a very short part of the $U$. nigricaudus reproductive period (only August). Besides this study, which includes only notations on the reproductive state of several individuals of this species in one particular month, there are no other studies dealing with the reproductive cycle of this species.

Comparing our results with other Urosaurus species, we found that a population of $U$. microscutatus studied in California (Asplund 1967) reaches maximum testis length during June. In contrast to this species, $U$. nigricaudus reproduction occurs during two periods; May and August. That is similar to other species like $U$. ornatus of Arizona (Tinkle and Dunham 1983), in which the females remain reproductive from May until late August. However, $U$. ornatus laid a maximum of three clutches of about seven eggs over an approximately 3 month period of this reproductive season (Tinkle and Dunham 1983).

Studying three populations of $U$. ornatus in Texas, Martin (1977) found that nearly all females from the three populations were in reproductive condition by April, and that ovulation began in the end of April and early May. The observed clutch size is correlated directly with female body size. However, in Texas, $U$. ornatus females laid 3 to 4 clutches (Martin 1977), and the clutch size decreases with time within the reproductive season. At El Comitán, $U$. nigricaudus laid only two clutches and the clutch size increases with the time within the reprodutive season.

Analyzing the reproductive biology of this Cape endemic species, we note an interesting difference with other Phrynosomatidae species; independent of whether females lay several clutches or produce only one brood, or whether the females are oviparous or viviparous, the males of most of iguanids usually show only one peak of growth of testis mass (Sceloporus scalaris, Ortega and Barbault 1986, Sceloporus formosus, Guillette and Sullivan 1985, Sceloporus virgatus, Ballinger and Ketels 1983).

Because the testicular mass change is usually a good indicator of the male reproductive activity (Mayhew and Wright 1970, Shrank and Ballinger 1973), it will be necessary to analyze histologically if both 
peaks of the testis mass observed in $U$. nigricaudus correspond to the sexual state of the animals (Hahn 1964).

This is the first study that includes all the months in which the adults remain active on the reproductive and fat body cycles of an abundant Cape endemic species

\section{ACKNOWLEDGMENTS}

This study was supported by the Centro de Investigaciones Biológicas del Noroeste and the Consejo Nacional de Ciencia y Tecnología of México. We thank Franco Cota, Reymundo Domínguez, Amado Cota, Federico Salinas, Cerafina Argüelles, Ricardo Aguilar, and Paty Galina for field assistance. Thanks also to two anonymous reviewers who improved an early version of this manuscript and to Ellis Glazier, for editing the English language text.

\section{RESUMEN}

Las características reproductivas de Urosaurus nigricaudus en El Comitán, Baja California Sur, México, fueron determinadas a través de la necropsia de 33 machos y 60 hembras colectadas durante el año de 1992. El tamaño de puesta promedio fue de $4.06 \pm 1.86$ huevos por hembra; en la primera puesta el promedio fue de 3.58 huevos y en la segunda puesta fue de 4.75 huevos por hembra. El tamaño testicular también se incrementó en dos ocasiones; en mayo y agosto. Los ciclos de machos y hembras estuvieron sincronizados. En comparación con otras especies de Urosaurus, U. nigricaudus es atípica dado que los machos muestran dos picos de masa testicular.

\section{REFERENCES}

Alvarez, S., P. Galina \& A. Ortega-Rubio. 1989. Structure and composition of two lizard communities of the Cape Region, Baja California Sur, México. Bull. of the Maryl. Herpetol. Soc. 25: 40-48.

Asplund, K.K. 1967. Ecology of lizards in the reclictual Cape flora, Baja California. Ame. Mid. Nat. 77: 462-475.

Ballinger R. E. \& D.J. Ketels. 1983. Male reproductive cycle of the lizard Sceloporus virgatus. J. Herpetol. 17: 99-102.
Galina, T.P. 1994. Estudio comparativo de tres especies de lacertilios en un matorral desértico de la región del Cabo Baja California Sur, México. Tesis de Maestría en Ciencias. Universidad Nacional Autónoma de México, México, D.F. 81 p.

Guillette L. J.Jr. \& W.P. Sullivan. 1985. Reproductive and fatbody cycles of the lizard, Sceloporus formosus. J. Herpetol. 19: 474-480.

Hahn, W.E. 1964. Seasonal changes in testicular and epididymal histology and spermatogenic rate in the lizard Uta stansburiana stejnegeri. J. Morphol. 115: 447-460.

Leon, J.L. \& E. Troyo 1985. Evaluación de un novedoso sistema de riego en Baja California Sur. p.100103. In Memorias de la Conferencia Internacional: Uso y Preservación de los recursos Biológicos Marinos y de Zonas Aridas. Centro de Investigaciones Biológicas. La Paz, Baja California Sur, México.

León de la Luz, J.L., R. Coria Benet \& M. Cruz Estrada. 1996. Fenología floral de una comunidad arido-tropical de Baja California Sur, México. Acta Bot. Mex. 35: 45-64.

Martin, P.S. 1977. Variation in reproductive productivity of range margin tree lizards (Urosaurus ornatus). Copeia: 82-95.

Mayhew, W. \& S.J. Wright. 1970. Seasonal changes in testicular histology of three species of lizards genus Uma. J. Morph. 130: 163-186.

Ortega A. \& R. Barbault. 1986.Reproduction in a high elevation mexican lizard Sceloporus scalaris. J. Herpetol. 20: 11-114.

Romero-Schmidt, H., A. Ortega, C. Arguelles, R. Coria \& F. Solis. 1994. The Effect of Two Years of Livestock Grazing Exclosure upon Abundance in a Lizard Community in Baja California Sur, México. Bull. Chicago Herp. Soc. 29 : 245-248.

Schrank, G.D. \& R. E. Ballinger. 1973. Male reproductive cycles in two species of lizards (Cophosaurus texanus and Cnemidophorus gularis). Herpetologica, 29: 289-293.

Stebbins, R.C. 1985. Western Reptiles \& Amphibians. Peterson Field Guides. Houghton Mifflin. Boston, Massachussets. 339 p.

Tinkle, D.W. \& A.E. Dunham. 1983. Demography of Tree Lizard, Urosaurus ornatus, in Central Arizona. Copeia 3: 585-598. 